\title{
ПРОФЕСИОНАЛНАТА ПОДГОТОВКА НА ОФИЦЕРИТЕ В БЪЛГАРИЯ (1878-1945 Г.)
}

\author{
С. Явашчев
}

\begin{abstract}
Явашчев С. Професионалната подготовка на офицерите в България (1878-1945 г.) В статията е разгледана системата за професионалната подготовка на българските офицери. Обърнато е специално внимание на ролята и мястото на военното училище, военната академия и школите за преподготовка на офицерите. Разгледано е и обучението им в конкретна държава в чужбина, като следствие от политическата обвързаност на България.

Ключови думи: българска армия; офицери; военно училище; военна академия.
\end{abstract}

Явашчев С. Профессиональная подготовка офицеров в Болгарии (1878-1945 гг.). В статье рассматривается система подготовки болгарских офицеров. Особое внимание уделяется роли и месту в этой системе Военного училища, Военной академии и курсов для переподготовки офицеров. Рассматривается их обучение за рубежом с учетом политической ориентации Болгарии.

Ключевые слова: болгарская армия; офицеры; Военное училище; Военная академия.

Yavashchev S.The Professional Training of Officers in Bulgaria (1878-1945). The article examines the system for the professional training of the Bulgarian officers. An accent is put on the role of the High Military School, of the Military Academy, and of the officers' schools. A particular country is chosen to illustrate this process, closely connected to the foreign policy of Bulgaria.

Keywords: Bulgarian army; Officers; High Military School - Sofia; Military Academy - Sofia.

Два са основните компоненти на всяка армия, без които тя не може да съществува: личният състав и въоръжението. От своя страна личният състав според функциите, които изпълнява, се разделя на команден и редови. Командният състав включва младши, средни, старши и висши командири. За да бъде армията готова да изпълни задълженията си, предвидени в Конституцията и съответните закони, нейният личен състав трябва да притежава висока професионална подготовка. За тази подготовка е от съществено значение образованието на командния състав на армията.

След Освобождението през 1878 г. в страната е създадена военнообразователна система, благодарение на която офицерите и генералите получават специални военни и общообразователни знания и умения, необходими им за ежедневната дейност в мирно и военно време. За да се подготви, офицерът изминава дълъг път, изпълнен с трудности и изпитания. През това време той натрупва много знания, умения и опит както в службата, така и в живота.

Всяка държава има своя военнообразователна система, която е в зависимост от нейните икономически възможности и военнополитическа доктрина, от числеността на армията, заобикалящата я стратегическа обстановка и пр. След възстановяването на нашата армия в нея също се изгражда такава система, която наред със заимстваното от чужбина, има и свои специфични национални особености. Благодарение на нея са подготвени десетки хиляди офицери, които вземат участие във войните на Третата българска държава и водят българския войник по бойните полета в Европа. Тя е в основата и на военнообразователната система в страната ни след края на Втората световна война.

\section{1. Подготовката на офицерски кадри за българската армия 1878-1918 г.}

Създаването на Българската земска войска налага необходимостта от военно училище за подготовка на офицери. Руският императорски комисар в България княз Александър Дондуков-Корсаков изтъква в свой рапорт до Санкт-Петербург необходимостта от откриването на българско военно училище, в което да се приемат здрави, образовани и талантливи младежи, и след успешно завършване на курса на обучение да бъдат назначени на 
съответстващите на знанията и командните им качества длъжности. С телеграма от 3 юни 1878 г. руският военен министър Дмитрий Милютин пише: „Императорът напълно одобри Вашето предложение за създаването на юнкерско училище... “, и Дондуков-Корсаков възлага на началника на Военния отдел при Временното руско управление генерал-майор Василий Золотарьов да проучи въпроса за създаване на военно училище в България.

Още в началото на юни 1878 г. са разработени „Положение за училището“ и „Програма“" за приемния изпит и са уточнени подробностите по откриването на военното училище. Кандидатите трябва да са на възраст не по-малка от 17 години и да са завършили четвърти гимназиален клас. Предвижда се във военното училище те да получат „научно и стройно образование, необходимо за един офицер“. Учебният курс се разделя на два класа: първи (общ) и втори (специален $)^{1}$.

Сформирана е учебна команда в Пловдив от 80 души, но впоследствие тя е допълнена и достига 106 души. През лятото на 1878 г. 19 унтерофицери от Българското опълчение са произведени в офицерско звание 2 .

През ноември 1878 г. командата е преобразувана във Военно училище и е преместена в София 3 . За място на училището е избрана сградата на бивша турска военна болница, разположена тогава извън града (на мястото на сегашния Централен военен клуб). Приемните изпити са по български език, руски език, Закон божи, математика, география, история.

В училището изцяло е възприета учебната система от руските военни училища, а за официален език е приет руският. Целта на подготовката е да се дадат необходимите теоретични, общообразователни и военни знания на младежите, постъпили в училището, за да могат да служат като младши офицери в българската армия.

Пьрвоначално оценяването на успеха на юнкерите се прави по петобалната система, а впоследствие се преминава към дванадесетобалната, при следното значение: 12 - отличен; 10 и 11 - много добър; 8 и 9 - добър; 6 и 7 - удовлетворителен; 4 и 5 - неудовлетворителен; 2 и 3 - слаб; 1 - много слаб. Тази система на оценяване на успеха, в общи линии, се запазва и през следващите десетилетия, а след Втората световна война се преминава към шестобалната система на оценяване.

Курсът на обучение в училището е 2 години, но за да се попълни армията с офицерски кадри, първият випуск на Военното училище е произведен предсрочно (за 5,5 месеца) през май 1879 г. На завършилите успешно пълния курс на обучение в училището се присвоява звание поручик. Сто офицери от него остават в армията на Княжеството, а 61 отиват в Източнорумелийската милиция.

В първите години след Освобождението българи са изпращани да се обучават и в Русия. Във Военното кавалерийско училище в Елисаветоград са изпратени на обучение 90 български младежи, а в пиротехническите школи в Петербург и Тула - 42 младежи ${ }^{4}$.

През 1880 г. се стига до извода, че 2-годишният курс на обучение е недостатъчен за добро усвояване на общообразователните и военните дисциплини. Поради това от същата година се преминава на 3-годишно обучение. Впоследствие се преценява, че и това не е достатъчно, и реално от 1881 г. обучението е 4-годишно. С някои промени тази продължителност на обучението се запазва до края на века.

До 1885 г. Военното училище подготвя и изпраща в частите на армията и на Източнорумелийската милиция 450 офицери (5 офицерски випуска). В руските военни училища се обучават 132 българи. Освен това български офицери редовно се изпращани на стаж в руската армия, а други завършват руски военни академии. Към 1885 г. в армията на Княжеството има 7 български офицери, завършили Николаевската военна академия на Генералния щаб, 3 офицери са завършили Артилерийската академия, 3 - Военноинженерната и 1 - Военноюридическата 5 .

В първите години след Освобождението трудно се решава въпросът с военното образование и квалификацията на офицери за Дунавската флотилия и Морската част. Пьрвоначално там служат само руски офицери. Въпреки че след 1882 г. 13 стипендианти заминават за обучение в Русия във Военноморското техническо и Военнопиротехническото училище в Петербург, до 1885 г. само двама от тях се връщат на служба във Флотилията и Морската част ${ }^{6}$.

През 1900 г. във Военното училище настъпват сериозни промени. Към него е открита военна гимназия, целта на която е бъдещите офицерски кадри да започват военното си 
обучение и възпитание в по-ранна възраст. През есента на 1900 г. са приети 240 младежи в трите гимназиални класа. Гимназията съществува до 1910 г.

От създаването му до 1903 г. Военното училище завършват 1400 негови възпитаници, въпреки че се обучават значително по-голям брой юнкери. Това се обяснява с високата взискателност към тях. В офицерско звание се произвеждат и други военнослужещи и граждани, които отговарят на определени условия: завършилите чуждестранно военно учебно заведение и произведени в офицерско звание в него; младежи със средно и висше образование, които след изслужване на задължителния срок на службата издържат изпит по програмата за Военното училище; фелдфебелите, след изслужване на пълния срок на службата си се зачисляват в запаса с производство в пьрво офицерско звание.

Освен Военното училище, което се превръща в център за повишаване на подготовката на офицери от частите, в системата на военното образование се включват още школите и курсовете за квалификация на младши и старши офицери. През 1882 г. към Военното училище е открита школа за подготовка на топографи за армията, която съществува 2 години. От 1889 г. към училището е сформирана „фелдшерска рота“ за подготовка на медицински и ветеринарни фелдшери. Още в началото на века в София започва да функционира Кавалерийска школа за ескадронни командири, а във Велико Търново е създадена Пехотна школа за ротни и дружинни командири ${ }^{7}$

През 1889 г. в Княжеството е открита Школа за подготовка на запасни поручици от пехотата, подчинена на началника на Военното училище. Същата се отделя като самостоятелно учебно заведение през 1892 г. В 1891 г. е открита и Школа за подготовка на запасни подпоручици от артилерията.

За получаване на висше военно образование офицерите са командировани в чужбина - до 1885 г. в руски военни академии, а след това в Белгия, Австрия, Италия и Франция. След подобряването на отношенията с Русия те отново са изпращани и там. Подготовката на морски офицери се извършва в чуждестранни военноморски учебни заведения. От 1892 г. до 1912 г. общо 434 офицери от българската армия завършват академии, школи, курсове и др. в чужбина. От тях 276 - в Русия, 75 - в Италия, 44 - във Франция, 31 - в Австрия и 8 - в Белгия 8 .

Образованието във Военното училище се базира на изучаването на основните военни дисциплини: тактика, топография, фортификация, артилерия, военна администрация, законознание, военна методика и етика, военна география, военна история, военна хигиена и др. През 1909 г. се правят сполучливи опити за диференциране на подготовката на юнкерите по родове войски. През пьрвата година те получават обща военна подготовка, а през втората пехотинците и кавалеристите се обучават отделно от артилеристите и пионерите (сапьорите).

След завършване на училището юнкерите се разпределят по родове войски според успеха им през годините на обучение. Тези с най-висок успех са разпределяни в артилерията, инженерните войски и кавалерията. Поради недостатъци на този подход, впоследствие той е изоставен и се преминава към обособяването по родове войски във всеки випуск.

Значително внимание в българската армия се отделя и за повишаване на специалната подготовка на офицерите от родовете войски. То се налага от промените във военната теория и въоръжението на армията, както и от предимно пехотния характер на обучението във военното училище. Специализацията на кавалерийските офицери става в съответната школа. За офицерите са създадени два курса: старши - за кандидати за ескадронни командири със срок на обучение 2 години, и младши - за новопостъпили офицери в кавалерията със срок на обучение 1 година. Програмата и за двата курса е специализирана и включва в теоретичната си част тактика и тактически задачи, история на конницата, фортификация, телеграфно и конно пионерно дело. В практическата част са включени различните видове езда, обездка на млади коне, практически занятия в учебния ескадрон и др.

През 1889 г. към Военното училище е открит курс за запасни офицери, който е с продължителност 9 месеца. В него ежегодно постъпват около 150 войници с четвъртокласно образование. По-късно този курс е заменен от дивизионни учебни команди за подготовка на запасни офицери. През 1901 г. в София е открита Школа за подготовка на запасни подпоручици в пехотата. 
За специалното образование на артилерийските офицери през 1906 г. се открива Артилерийска школа при Военното министерство. Предназначението ѝ е да запознае артилерийските началници с новата материална част, с теоретичните основи на новите правила за стрелба и с новите идеи за използването на артилерията в боя. Срокът на обучение е до 15 дни. През 1907 г. е организиран курс по висша математика за офицерите, завьршили през същата година Военното училище и назначени в артилерията. Срокът на обучение е една година. Изучават се висша алгебра, аналитична геометрия, диференциални и интегрални изчисления, рационална механика, теория на артилерийската стрелба, тактика на артилерията, езда и фехтовка 9.

В навечерието на Балканските войни 1912-1913 г. Военното училище е подчинено на Щаба на армията. След извършване на мобилизацията на българската армия от Военното училище за различни формирования на действащата армия заминават 463 души. Офицерите от училището са назначени на различни командни и щабни длъжности, а юнкерите - като младши командири вземат участие в двете Балкански войни.

През войните Военното училище е закрито в продължение на 10 месеца и започва отново да функционира на 1 август 1913 г. Извършват се сериозни организационни промени в структурата на училището и в учебното съдържание. Рязко се увеличава ежегодният прием на младежи за обучение в училището. Опитьт от двете Балкански войни налага промяна и в учебните програми. От една страна, те са насочени към разширяване на полевото обучение и обрьщане на по-голямо внимание на стрелбата. От друга - по-широко са застъпени науките за човека (физиология, военна педагогика и психология, военна етика, социология и др.). Въвежда се и дисциплината „Философия на войната““.

Балканските войни показват, че бъдещите военни конфликти ще са продължителни и в тях решаваща е ролята на човешкия фактор. От неговата морално-психологическа подготовка зависи до голяма степен изходът на войната. Чрез посочените учебни дисциплини се изучават не само теоретичните постановки, но и се акцентира върху целите, методите, критериите, формите, средствата и ефективността на обучението по тези учебни дисциплини.

В годините на Пьрвата световна война Военното училище не е разформировано, а продължава да действа, но се преминава на съкратени срокове за подготовка - около 1,5 години за юнкерите и около 5 месеца за школниците, подготвяни за запасни офицери. Извършените промени в учебните програми са свързани с новостите в средствата за воюване и във военното дело.

По време на Първата световна война Военното училище се слива с Школата за запасни подпоручици. Първоначално се предвижда същата да започне да функционира през есента на 1915 г. В действителност Школата започва да функционира през март 1916 г. За целия период от участието на България във войната Школата завършват 4 випуска (6300 души) запасни офицери със звание „офицерски кандидат“.

Развитието на военното дело и военната наука налагат промени в подготовка на българските офицери зад граница. Нараства броят на обучаваните в чужбина, най-вече на тези, които ще заемат висши щабни и командни длъжности ${ }^{10}$.

Но обучението на български офицери в чуждестранни академии има и недостатъци. Там те се обучават по техни устави и правилници, според чужди схващания за водене на войната и военните действия, които не са съобразени с особеностите на нашата армия (структура, организация, численост, въоръжение, вероятни противници и пр.).

Затова към края на 1911 г. и първата половина на 1912 г. се пристъпва към създаването на Военна академия, а в Народното събрание е гласуван специален закон ${ }^{11}$. Нейната цел е „да разпространи висши военни знания в армията и да дава на офицерите нужната основа за по-нататъшно усъвършенстване и подготовка за командване на отделни части и за служба в Генералния щаб“.

Курсът на обучение в Академията е 3 години. Ежегодно в нея, чрез конкурсни изпити, трябва да постъпват не повече от 20 души. Условието за кандидатстване е офицерите да са били на военна служба в армията най-малко 4 и най-много 8 години, от които половината да са били на строева длъжност, да са положително атестирани, да са здрави и физически добре развити, да са издържали всички конкурсни изпити. За преподаватели по военните дисциплини след конкурс се назначават старши офицери с висше военно образование за срок от 4 години ${ }^{12}$. 
Предвижда се изучаването на стратегия, тактика, военна история, българска история, генералщабна служба, организация и администрация, артилерия, фортификация, военни съобщения, топография, военна география, сведения по морската част, сведения по международно, конституционно и гражданско право, политическа икономия, западен език и език на съседните държави ${ }^{13}$. Оценяването на знанията става по 12-бална система, като според важността на учебната дисциплина се умножава със съответен коефициент.

Първата балканска война спира началото на учебния процес в академията. След Междусъюзническата война през юли 1913 г. за пръв началник на Военната академия е назначен полковникът от Генералния щаб Асен Пападопов ${ }^{14}$. Академията започва реално да съществува от 4 януари 1915 г., но поради включването на България в Първата световна война, тя преустановява временно своята дейност.

\section{2. Военнообразователната система в България след Първата световна война 1919-1945 г.}

Още след края на Първата световна война Министерството на войната и Щабът на армията започват да тьрсят начини, за да организират система за подготовка на офицерския състав в условията на Ньойския мирен договор от 1919 г. Съставна част на системата отново са Военното училище, школите и курсовете, гражданските висши учебни заведения.

Ограничителните клаузи на Ньойския договор рефлектират и върху Военното училище. Член 73 от договора предвижда в страната да има „най-много едно военно училище“. При това юнкерите и офицерите от училището влизат в общата численост на армията. Това налага намаляване на съществуващия юнкерски състав в училището и уволнението на част от него.

За прием във Военното училище през 20-те години на XX век няма конкурсни изпити. Класирането се извършва по дипломите от завършено средно образование и в зависимост от резултатите на медицинския преглед. Предвидени са и редица условия, на които трябва да отговарят кандидатите: да са български поданици, не по-възрастни от 22 години, с примерно или похвално поведение и физически здрави ${ }^{15}$.

Когато става ясно, че предстои отпадането на военните клаузи на Ньойския договор и на българската армия ще са ѝ необходими повече офицери с висше военно образование, е въведен нов правилник за постъпване във Военното училище. Съществената промяна в него е, че за кандидатите се въвежда конкурсен и психотехнически изпит. Конкурсните изпити са по математика, история на България, география на България, беседа по свободна тема. Целта на този изпит е да провери общата култура, логиката на разсъждение на кандидатите, начина на мислене, правописа и краснописа. Чрез психотехническия изпит трябва да се провери дали интелектуалните, нравствените и психическите качества на кандидатите са такива, каквито трябва да притежава един бъдещ офицер ${ }^{16}$.

Учебните планове на училището са почти същите, както преди войните, но учебните програми претърпяват сериозни промени. Те са съобразени със собствения и чуждия опит от току-що завьршилите войни и преди всичко от Пьрвата световна война. В училището продължава да се прилага възприетия подход за всестранна подготовка на бъдещите офицери. Изучават се стратегия, тактика, родове войски, военна администрация, военна история, военна география, военна педагогика и психология и др. Продължава и изучаването на общообразователни дисциплини (история на България, история на балканските народи, статистика, политикономия, общо държавно и българско конституционно право, международно право и право на война, административно право, висша математика, френски език, руски език $)^{17}$.

За изпълнението на учебните планове и програми, а и за възпитанието на обучаемите, важна е и ролята на преподавателския състав. За преподаватели с царска заповед се назначават отлично подготвени офицери с висше военно образование, автори на научни трудове или доказали компетентността си по съответния учебен предмет. Като преподаватели по общообразователните дисциплини се привличат професори от Софийския държавен университет $^{18}$. По този начин се оформя академичното крило на българската военна мисъл ${ }^{19}$.

C командно-преподавателския състав на училището се водят занятия, целта на които е да се усъвършенства тяхната подготовка; да се уеднаквят възгледите им по спорни 
проблеми; да се запознаят с новостите на военното дело в чужбина и пр. В училището се провеждат конференции за разясняване на редица проблеми от действащите в армията устави, правилници и наставления ${ }^{20}$.

За подобряване на качеството на обучението във Военното училище се обръща внимание и на учебно-материалната база. За нагледното преподаване на учебните дисциплини са обзаведени кабинети по всички дисциплини. На юнкерите се осигуряват безплатни учебници и записки. Има библиотека с богат фонд от учебна и художествена литература, а за физическата подготовка на юнкерите са изградени физкултурен салон, зала и стадион ${ }^{21}$.

Със специален закон от 1924 г. Военното училище се признава за висше специално учебно заведение. По такъв начин випускниците на училището се ползват с права на завършили висше образование, тъй като дотогава образованието от Военното училище не е със статут на висше.

Нарасналите изисквания към армията и нейния офицерски състав са причина за съществуването и на профилирани военни училища. В страната има морско и летателно училища. Със специален указ от 1942 г. морското училище се преименува във Военноморско училище с три отдела: за строеви морски офицери, за навигационен команден състав и за минни морски офицери. Срокът на обучението е 3 години. От учебната 1942/43 г. към него се открива гимназиален отдел, а през 1943 г. - морски отдел на Школата за запасни офицери към училището 22 .

Обучението на морски офицери продължава в училището до 1941 г., след което то е преместено в Созопол. Военните летци се обучават във Военното училище до 1947 г. Летателната им подготовка преминава на летището в Казанльк ${ }^{23}$.

Повишените изисквания към кандидатите за постъпване във Военното училище са причина през 1937 г. отново да се открие военна гимназия към училището. Условията за постъпване в нея са желаещите да са православни и български поданици; да са на възраст от 17,5 до 19,5 г; да не са изключвани от училище през последните 3 години преди кандидатстването; да са благонадеждни и физически здрави ${ }^{24}$.

След включването на България в Тристранния пакт на 1 март 1941 г. сроковете за обучение на юнкерите от 3 години са намалени на 2 години. Това се налага от проведената мобилизация на българската армия и нуждата от повече офицерски кадри след нейното военновременно развръщане.

Едно от важните направления в дейността на училището през Втората световна война e, че още от самото ѝ начало се вземат мерки за изучаване на новостите в средствата и начините за воюване. Това се отнася предимно за германския боен опит от Западния и Източния фронт.

Динамиката на промяната на броя на преподавателите, на постьпилите и завършилите успешно Военното училище след Първата световна война са посочени в таблицата ${ }^{25}$ :

\begin{tabular}{|c|c|c|c|c|c|c|c|}
\hline $\begin{array}{c}\text { Учебна } \\
\text { година }\end{array}$ & $\begin{array}{c}\text { Препо- } \\
\text { даватели }\end{array}$ & $\begin{array}{c}\text { Постъ- } \\
\text { пли във } \\
\text { Ву }\end{array}$ & $\begin{array}{c}\text { Завър- } \\
\text { шили } \\
\text { вУ }\end{array}$ & $\begin{array}{c}\text { Учебна } \\
\text { година }\end{array}$ & $\begin{array}{c}\text { Препо- } \\
\text { даватели }\end{array}$ & $\begin{array}{c}\text { Постъ- } \\
\text { пили във } \\
\text { Ву }\end{array}$ & $\begin{array}{c}\text { Завър- } \\
\text { шили } \\
\text { вУ }\end{array}$ \\
\hline $\mathbf{1 9 1 9 / 1 9 2 0}$ & 16 & 406 & - & $1930 / 31$ & 38 & 296 & 125 \\
\hline $\mathbf{1 9 2 0} / 1921$ & 17 & 437 & - & $1931 / 32$ & 40 & 263 & 83 \\
\hline $\mathbf{1 9 2 1 / 1 9 2 2}$ & 16 & 277 & 99 & $1932 / 33$ & 47 & 255 & 80 \\
\hline $\mathbf{1 9 2 2 / 1 9 2 3}$ & 21 & 245 & 74 & $1933 / 34$ & 44 & 250 & 85 \\
\hline $\mathbf{1 9 2 3} / \mathbf{1 9 2 4}$ & 16 & 278 & 44 & $1934 / 35$ & 43 & 276 & 80 \\
\hline $\mathbf{1 9 2 4} / \mathbf{1 9 2 5}$ & 25 & 263 & 65 & $1935 / 36$ & 47 & 310 & 77 \\
\hline $\mathbf{1 9 2 5 / 1 9 2 6}$ & 25 & 295 & 89 & $1936 / 37$ & 37 & 359 & 108 \\
\hline $\mathbf{1 9 2 6 / 1 9 2 7}$ & 24 & 294 & 93 & $1937 / 38$ & 38 & 415 & 112 \\
\hline $\mathbf{1 9 2 7 / 1 9 2 8}$ & 33 & 311 & 97 & $1938 / 39$ & 37 & 498 & 127 \\
\hline $\mathbf{1 9 2 8} / \mathbf{1 9 2 9}$ & 28 & 337 & 91 & $1939 / 40$ & 40 & 556 & 159 \\
\hline $\mathbf{1 9 2 9} / \mathbf{1 9 3 0}$ & 43 & 323 & 113 & & & & \\
\hline
\end{tabular}


В навечерието и по време на Втората световна война до 1944 г. юнкери от Военното училище са изпращани за обучение и в други страни. През пролетните и летните месеци летците провеждат практически занятия в различни авиационни школи и училища в Германия, Италия, Полша и Унгария, а моряците - във флота на Германия. Юнкери - пехотинци, свързочници и сапьори, са изпращани на обучение в Германия.

И след Първата световна война в страната съществуват школи, където офицерите повишават професионалната си подготовка. Такива са Школата за ротни, батарейни и ескадронни командири; Школата за кандидат-дружинни командири; школи към всяка инспекция на родовете войски ${ }^{26}$. Периодично, по решение на Щаба на войската, се открива и школа за кандидати за командири на полкове ${ }^{27}$. През тези школи преминават всички командири, на които им предстои да бъдат повишени в длъжност.

Поради ограниченията на Ньойския договор, след Първата световна война Школата за запасни офицери е закрита. Едва през 1926 г. тя започва отново да действа, отначало в Шумен, а след това се установява в София. Школата има пехотен, артилерийски, инженерен и въздушен отдел. Обучението в нея е една година, след което школниците дослужват службата си в поделенията ${ }^{28}$.

След Пьрвата световна война и особено след сключването на Балканския пакт в началото на 30-те години на XX век, България е заобиколена от държави, всяка от които е потенциален противник в бъдеща война. Това налага военните специалисти да изучават не само организацията на армиите на съседните страни и тяхното въоръжение, но и военнообразователната им система, която подготвя бъдещите им командири.

Въпреки че по отношение на образованието на населението и на донаборниците съседните държави значително изостават от България, в тях се отделя нужното внимание за образованието и подготовката на командния състав на армиите им. Например за сухопътните войски на Гърция има Военно училище, Военна академия и школи за родовете войски; за въздушните войски - три школи, за флота - Военноморско училище, Военноморска академия и съответните школи ${ }^{29}$.

Между двете световни войни Югославия също притежава разгьрната мрежа от военни учебни заведения. Между тях са Военната академия (Белград), Морската академия (Дубровник), Интендантската академия (Белград), Военното училище (Белград), Военноморското училище (Шибеник), Школата за запасни офицери (Белград и Сараево), Висшата въздухоплавателна школа (Нови Сад), Хидропланно училище (Катаро), Училище за противогазова атака и отбрана (Крагуевац), Училище за противовъздушна отбрана (Скопие) ${ }^{30}$.

След Първата световна война, съгласно военните клаузи на Ньойския договор, страната няма право да има Военна академия и Военното министерство е принудено да я разформирова $^{31}$. Едва през ноември 1923 г. Академията започва отново да функционира, но тайно, под името „Преподавателски курс“ към Военното училище. Той е естествено продължение и приемник на Военната академия и е разположен в района на Военното училище. В същото време курсът има самостоятелен статут, команден и преподавателски състав. Офицерите идват на учебни занятия в цивилно облекло. Всички заповеди, отнасящи се за курса, се издават устно. Целта е при евентуална проверка от страна на Контролната комисия от представители на държавите победителки, да не се констатират нарушения на военните клаузи на Ньойския договор. Скритото ѝ функциониране продължава до 1935 г., след което тя отново съществува под името Военна академия ${ }^{32}$.

От 1925 до 1935 г. включително приемането на обучаеми във Военната академия става през една година, а след това - всяка година (с изключение на 1938 г.). От началото на 30-те години на XX век се увеличава броят на приеманите във Военната академия офицери и през учебната 1933/1934 г. те са $88^{33}$. Условията, на които трябва да отговарят офицерите, желаещи да постъпят в Академията, са да бъдат отлично атестирани; да са напълно здрави и без физически недостатьци; да са прослужили най-малко 5 години във войската и да са с офицерско звание до майор; да издържат с успех конкурсните изпити ${ }^{34}$.

В Академията офицерите преминават тригодишен теоретичен курс и двегодишен стаж. Завършилите Академията трябва да преминат успешно този стаж, за да станат генералщабни офицери. Освен в своя род войска, стажът се провежда и в другите родове 
войски, където офицерите ръководят повече от половината занятия, предвидени в годишния план. Предвижда се проучване и разработване на военноучебни въпроси, преглед на чуждестранна военна литература, написване на част от правилник или наставление, военножурналистическа дейност, решаване на тактически и оперативни задачи.

Опитът от Първата световна война и развитието на военното дело след нея налагат да се обърне внимание на диференцираното обучение. Затова през 1929 г. към Преподавателския курс е открита Висша артилерийска инженерна школа, в която са извикани за преподготовка офицери, завършили различни чуждестранни инженерни академии. Школата функционира до 1932 г., когато е закрита. През есента на 1931 г. към Преподавателския курс е създаден Интендантски отдел ${ }^{35}$.

За повишаване на военнотеоретичната подготовка на офицерите в Академията се изучават следните дисциплини: стратегия, тактика, военна история, военна география, тактика на родове войски, генералщабна служба, морско дело и др. ${ }^{36}$ След 1930 г. оперативното изкуство, оформило се като самостоятелен дял на военното изкуство, започва да се преподава отделно от общата тактика. По това време в него се изучават действията на отделната армия и на групата армии.

За повишаване на общата култура на офицерите в Академията се изучават и редица общообразователни дисциплини: социология; политическа икономия; общодържавно и конституционно право, гражданско и военно право; международно право; журналистика и пропаганда; чужди езици и др.

От първия випуск на Академията до началото на Втората световна война обучаемите разработват две теми, едната през втората година, която е по историческа тема и е като пробна дипломна работа, и втората - през третата година, от областта на военното изкуство (стратегия, оперативно изкуство, тактика), която е дипломна работа. След 1939 г. на обучаемите се дава само по една тема, която е дипломна работа, с която те завършват обучението си $^{37}$.

В годините непосредствено до началото на Втората световна война средно около 110 офицери завършват Военната академия: 1934 г. - 21; 1936 г. - 19; 1937 г. - 19; 1938 г. - 23; 1939 г. - 10. През това време други 18 офицери завършват Интендантския отдел на академията ${ }^{38}$. От 1942 г. курсьт на обучение в Академията е намален на две години, поради военновременното разгръщане на българската армия и нуждата от повече офицери с висше военно образование за нея.

Това състояние на положението с военноакадемичните кадри, необходимостта от форсирано подготвяне на нови кадри с военноакадемично образование, както и невъзможността да се удовлетворят потребностите на нашата армия от такива кадри чрез обучение в България са причина след Първата световна война български офицери да получават висше военно образование и в чужбина, въпреки забраната, наложена от военните клаузи на Ньойския мирен договор.

През 20-те години на XX в. офицерите се изпращат на обучение предимно в италиански военноучебни заведения, тъй като по това време Италия е единствената страна от Великите сили, която проявява стремеж за военно сътрудничество с България. За да се заобиколят военните клаузи на Ньойския договор, българските офицери, които постъпват в артилерийската и в инженерната академия, се изпращат там като изучаващи италиански език. В началото на 30-те години български офицери, под формата на летци от гражданската авиация, постьпват в италиански военни училища. За това има и една допълнителна причина - по това време Италия е от водещите държави в самолетостроенето и използването на авиацията за военни цели ${ }^{39}$.

През 1935 г. Германия едностранно отхвърля Версайския договор и отваря широко вратите на военноучебните си заведения за подготовка на български офицери от различните родове войски. Изключение се прави за обучението в германската военновъздушна академия, защото доктрината на Гьоринг се пази в най-строга тайна ${ }^{40}$.

В средата на 1930-те години Франция и Англия също негласно нарушават военните клаузи на Ньойския договор. Те не само ни осигуряват военни доставки, но приемат на обучение и наши офицери във военноучебните си заведения. Поради политическата ориентация на България към Италия и най-вече към Германия, тя не се възползва пълноценно от предоставената ѝ възможност ${ }^{41}$. Доказателство за това са данните за офицерите, 
обучавани в Италия, Германия и Франция през втората половина на 1930-те години, т.е. в навечерието на Втората световна война ${ }^{42}$ :

\begin{tabular}{|c|c|c|c|c|}
\hline Години & Дьржави & Италия & Германия & Франция \\
\hline 1934 & & 9 & 4 & - \\
\hline 1935 & & 14 & 4 & 1 \\
\hline 1936 & & 12 & 7 & 1 \\
\hline 1937 & & 14 & 19 & 1 \\
\hline 1938 & & 9 & 14 & 4 \\
\hline 1939 & & 6 & 12 & 1 \\
\hline & Всичко: & 64 & 60 & 8 \\
\hline
\end{tabular}

За да ограничи отрицателното влияние на чуждестранните военни теории върху българските схващания, завършилите военна академия в чужбина след завръщането си в България държат изпит по стратегия и оперативно изкуство ${ }^{43}$.

Освен редовното обучение на български офицери във военноучебни заведения в чужбина, на специализирани курсове и стаж с различна продължителност се изпращат офицери от всички родове войски. През разглеждания период наши офицери се изпращат на стаж и курсове предимно в Италия (артилеристи и летци) и в Германия (летци, моряци, танкисти, парашутисти, зенитчици и др.). До 1939 г. български офицери са изпращани на специализация и във Франция (артилеристи, кавалеристи, сапьори), Англия и Полша (летци $)^{44}$.

В хода на Втората световна война германското командване открива в гр. Ниш немско бойно училище. В него преминават курс на обучение български офицери от различни родове войски. Целта на това обучение е офицерите от нашата армия да се запознаят с новостите по фронтовете на войната, прилагани от воюващите държави ${ }^{45}$.

Освен във военни учебни заведения, след Първата световна война български офицери получават образование и в граждански такива. За нуждите на военните съдилища от офицери с юридическо образование периодично, чрез конкурсен изпит, Щабът на войската изпраща офицери да се обучават в Юридическия факултет на Софийския университет. След завършване на следването си те преминават едногодишен стаж и се назначават за военни съдии ${ }^{46}$.

С разрешение от Щаба на войската и чрез конкурсни изпити офицери от армията имат възможност да повишат образованието си и в Свободния университет. Това обаче се практикува само в първите години след Първата световна война. От 1922 г. Министерството на войната забранява офицери да посещават Свободния университет ${ }^{47}$. Основната причина за това е те да бъдат предпазени от разгарящите се партийнополитически борби, които проникват и в атмосферата на Свободния университет.

$$
* * *
$$

От изложеното дотук могат да се направят следните обобщения:

- Системата за подготовка на офицерски кадри в България непрекъснато е усъвършенствана. Още в първите години след Освобождението се полагат основите на нашата военнообразователна система, която функционира успешно през разглежданите хронологични граници. Благодарение на нея са подготвени десетки хиляди командири и началници от различен ранг, които дават своя принос както във войните, които води България, така и в мирновременните периоди от развитието на нашата армия ${ }^{48}$.

- По време на войните 1912-1918 г. Министерството на войната и Щабът на армията подхождат различно при използването на Военното училище. Грешката от разформироването му по време на Балканските войни е отчетена и през Пьрвата световна война то продължава да функционира при съкратени срокове и увеличен прием. По такъв начин за целия период на войната завършват 1400 юнкери от 4 випуска, а Школата за запасни подпоручици - 6300 школници, също от 4 випуска. 
- Военната академия, като неразделна част от военнообразователната система в нашата армия, допринася много за професионалната подготовка на офицерския състав. Учебните планове и учебните програми позволяват обучаващите се в нея да са винаги в течение с новостите в развитието на военното дело. В това отношение целесъобразно е използван и опитьт на чуждестранни военни школи чрез изпращане на наши офицери на обучение, стаж или практика в чужди военноучебни заведения.

- За качеството на нашата военнообразователна система говори и фактът, че през 30-те години и в годините на Втората световна война някои държави (Хърватска) изпращат на обучение у нас свои офицери, а други (Албания) правят опити да изпратят.

- Характерно за целия период от Освобождението до края на Втората световна война е това, че подготовката на офицери с отлична професионална подготовка не е само личен и ведомствен, но и държавнически въпрос. Изключително големи са грижите, които държавното и военното ръководство на България полагат за подготовката на знаещи, опитни и способни офицери. По този начин е създадена национална българска военнообразователна система за подготовка на висококвалифицирани офицери.

1 Държавен военноисторически архив (по-нататьк - ДВИА). Ф. 42-к. Оп. 1. А.е. 31. Л. 3-12.

2 Българската армия 1877-1919. София, 1988. С. 33.

3 ДВИА. Ф. 1. Оп. 1. А.е. 2. Л. 6.

${ }^{4}$ Българската армия ... С. 34.

${ }^{5}$ Пак там. С. 52.

${ }^{6}$ Пак там.

${ }^{7}$ Пак там.

${ }^{8}$ Пак там. С. 112.

${ }^{9}$ Пак там. С. 227

${ }^{10}$ Няколко мисли за една военна академия в София // Военен журнал. 1896. № 8. С. 248.

${ }_{11}^{11}$ Дьржавен вестник. 1912. № 136. 1 ноември.

${ }^{12}$ Наредба за Военната академия. София, 1914. С. 1.

13 Заимов Сm. Из историята на българската военна академия // Военноисторически сборник. 1959. № 4. С. 94.

14 Заповед по Действащата армия № 138, 11 юли 1913 // Министерски заповеди 1913 // Военноисторическа библиотека.

${ }^{15}$ Пак там. С. 7.

${ }^{16}$ Правилник за приемане на младежи за възпитаници във ВНВУ. София. 1936. С. 3-8.

${ }^{17}$ Пак там. С. 51-52; Програма на материала по разните предмети, които се изучават в курсовете на Военното на Н. В. училище. София, 1925. С. 2-3; Йовов М. Военното на Негово Величество училище от основаването му до днес 1878-1934. София, 1934. С. 315.

${ }^{18}$ Правилник за Военното на Н. В. училище... С. 4.

19 ДВИА. Ф. 1. Оп. 5. А.е. 538. Л. 4-6.

${ }^{20}$ Военното на Негово Величество училище. София, 1929. С. 15; Йовов М. Военното на Негово Величество училище... С. 331.

21 ДВИА. Ф. 26. Оп. З. А.е. 254. Л. 59; Ф. 22. Оп. 3. А.е. 312. Л. 30, 33; А.е. 326. Л. 13.

22 Държавен вестник. 1942. № 17. 26 март.

23 Правилник за морското училище. София, 1942; Строго поверителна министерска заповед № 207. 1930. 24 ноември.

${ }^{24}$ Правилник за приемане на младежи във Военната гимназия при Военното на Н. В. училище. София, 1937. С. 2.

25 Данните са от Статистическите годишници на Царство България 1919-1944 г. В тях няма данни за след 1940 г.

${ }^{26}$ ДВИА. Ф. 1. Оп. 5. А.е. 534. Л. 107; Ф. 22. Оп. 3. А.е. 289. Л. 298; Правилник на Школата за командири на роти, батареи и ескадрони. София, 1928. С. 3 ; Правилник на школата за кандидат-дружинни командири и приравнени. София, 1928. С. 6.

${ }^{27}$ Поверителна министерска заповед. 1933. № 170.2 авг.

28 ДВИА. Ф. 4. Оп. 1. А.е. 139. Л. 1156.

${ }^{29}$ Иванов С. Военна география на Гърция. София, 1931. Ръкопис във Военноисторическа библиотека. С. $47-48$

${ }^{30}$ Иванов С. Записки по военна география на Югославия. София, 1939. С. 39.

${ }^{31}$ Дьржавен вестник. 1920. № 221. 29 дек.

32 ДВИА. Ф. 040. Оп. 1. А.е. 1. Л. 79. 
${ }_{33}$ Военна академия „Георги Стойков Раковски“. Исторически очерк. София, 1990. С. 23.

${ }^{34}$ ДВИА. Ф. 1. Оп. 5. А.е. 538. Л. 7; Поверителна министерска заповед. 1932. № 104. 25 ян.

35 ДВИА. Ф. 1517. Оп. 1. А.е. 3. Л. 32.

${ }^{36}$ Пак там. А.е. 5. Л. 95.

37 Заимов Ст. Из историята на българската военна академия. С. 100.

${ }^{38}$ Пак там. С. 97.

39 ДВИА. Ф. 040. Оп. 1. А.е. 1. Л. 206; Димитров И. Българо-италиански политически отношения 1922-1943. София, 1976. С. 173.

40 ДВИА. Ф. 22. Оп. З. А.е. 293. Л. 92; Марков Г. Българо-германски отношения 1931-1939. София, 1984. С. $83,92$.

${ }^{41}$ ДВИА. Ф. 22. Оп. 3. А.е. 293. Л. 166; А.е. 296. Л. 354; А.е. 297. Л. 55; А.е. 301. Л. 327; А.е. 302. Л. 389.

${ }^{42}$ Пак там. А.е. 296. Л. 354; А.е. 301. Л. 327; А.е. 302. Л. 389.

${ }^{43}$ Пак там. А.е. 303. Л. 25.

${ }_{44}$ ДВИА. Ф. 28. Оп. 1. А.е. 191. Л. 20, 66; Ф. 22. Оп. 3. А.е. 293. Л. 97, 153, 303; А.е. 299. Л. 15; А.e. 293. Л. 54, 63, 93, 107, 130.

${ }^{45}$ Пак там. Ф. 22. Оп. 1. А.е. 321. Л. 393; А.е. 322. Л. 58; А.е. 323. Л. 33. До юни 1944 г. немското бойно училище в гр. Ниш завършват 105 командири на дружини, 267 командири на роти и 526 командири на взводове от пехотата в нашата армия.

${ }^{46}$ Крапчански В. и др. Кратьк обзор на бойния състав, организацията, използването и мобилизацията на българската армия от 1878 до 1944 г. София, 1964. С. 140.

${ }^{47}$ Народна отбрана. 1922. № 807. 29 юли.

48 От основаването си до септември 1944 г. Военното училище завършват 8070 офицери. Наймальк е 10-и випуск (1888 г.) - 25 души, а най-голям е випуск „Орловски“ (1915 г.) - 435 души. 